\title{
The decolorization and mineralization of Acid Orange 6 azo dye in aqueous solution by advanced oxidation processes: A comparative study
}

\author{
Hao-Jan Hsing ${ }^{\text {a }}$, Pen-Chi Chiang ${ }^{\text {a,* }}$, E.-E. Chang ${ }^{\mathrm{b}}$, Mei-Yin Chen ${ }^{\mathrm{a}}$ \\ ${ }^{a}$ Graduate Institute of Environmental Engineering, National Taiwan University, 71 Chou-Shan Road, Taipei 106, Taiwan, ROC \\ ${ }^{\mathrm{b}}$ Department of Biochemistry, Taipei Medical University, 25 Wu-Shin Street, Taipei 106, Taiwan, ROC \\ Received 31 May 2005; received in revised form 3 October 2005; accepted 19 May 2006 \\ Available online 7 November 2006
}

\begin{abstract}
The comparison of different advanced oxidation processes (AOPs), i.e. ultraviolet (UV)/ $/ \mathrm{TiO}_{2}, \mathrm{O}_{3}, \mathrm{O}_{3} / \mathrm{UV}$, $\mathrm{O}_{3} / \mathrm{UV} / \mathrm{TiO}_{2}$, Fenton and electrocoagulation (EC), is of interest to determine the best removal performance for the destruction of the target compound in an Acid Orange 6 (AO6) solution, exploring the most efficient experimental conditions as well; on the other hand, the results may provide baseline information of the combination of different AOPs in treating industrial wastewater. The following conclusions can be drawn: (1) in the effects of individual and combined ozonation and photocatalytic UV irradiation, both $\mathrm{O}_{3} / \mathrm{UV}$ and $\mathrm{O}_{3} / \mathrm{UV} / \mathrm{TiO}_{2}$ processes exhibit remarkable TOC removal capability that can achieve a $65 \%$ removal efficiency at $\mathrm{pH} 7$ and $\mathrm{O}_{3}$ dose $=45 \mathrm{mg} / \mathrm{L} ;(2)$ the optimum $\mathrm{pH}$ and ratio of $\left[\mathrm{H}_{2} \mathrm{O}_{2}\right] /\left[\mathrm{Fe}^{2+}\right]$ found for the Fenton process, are $\mathrm{pH} 4$ and $\left[\mathrm{H}_{2} \mathrm{O}_{2}\right] /\left[\mathrm{Fe}^{2+}\right]=6.58$. The optimum $\left[\mathrm{H}_{2} \mathrm{O}_{2}\right]$ and $\left[\mathrm{Fe}^{2+}\right]$ under the same HF value are 58.82 and $8.93 \mathrm{mM}$, respectively; (3) the optimum applied voltage found in the EC experiment is $80 \mathrm{~V}$, and the initial $\mathrm{pH}$ will affect the $\mathrm{AO} 6$ and TOC removal rates in that acidic conditions may be favorable for a higher removal rate; (4) the AO6 decolorization rate ranking was obtained in the order of $\mathrm{O}_{3}<\mathrm{O}_{3} / \mathrm{UV}^{2} \mathrm{O}_{3} / \mathrm{UV} / \mathrm{TiO} \mathrm{O}_{2}<\mathrm{EC}<\mathrm{Fenton}$; (5) the ranking of TOC removal efficiency of selected AOPs was in the order of $\mathrm{O}_{3}=$ Fenton $<\mathrm{EC}_{2} \mathrm{O}_{3} / \mathrm{UV}_{<}<\mathrm{O}_{3} / \mathrm{UV} / \mathrm{TiO} \mathrm{O}_{2}$ for 30 min of reaction time.
\end{abstract}

(C) 2006 Elsevier B.V. All rights reserved.

Keywords: Azo dye; Ozonation; UV; Fenton; Electrocoagulation; TOC removal

\section{Introduction}

Azo dyes have been used in many industrial processes, especially in the textile industry that applies dyeing and finishing technologies to color synthetic fabric. The spent dye solution, along with unreacted chemicals, is discharged into the wastewater treatment system. Residual colors in wastewater are difficult to remove entirely by biological and/or chemical treatment processes. The effluent containing residual color and compounds that are not easily biodegradable, may cause environmental concerns and may be aesthetically displeasing. Although sodium hypochlorite $(\mathrm{NaOCl})$ added to effluent may remove residual colors effectively, its high cost and environmental problems of biological toxicity must be taken into consideration [1]. Due to

\footnotetext{
* Corresponding author. Tel.: +88622362 2510; fax: +886223661642.

E-mail address: pcchiang @ntu.edu.tw (P.-C. Chiang).
}

the difficulty of removing dye residues from wastewater by traditional wastewater treatment methods, advanced oxidation processes (AOPs) have become the most promising procedures to treat textile wastewater containing dye residues in terms of effective decolorization and reduction of the refractory pollutants.

Ozonation is one of the AOPs that has been applied in water treatment for years. Because of its strong oxidative ability, ozone can degrade organic pollutants [2] and destroy microbes in the form of ozonated water. The combination of ozonation with ultraviolet (UV) irradiation and/or photocatalysts, that has been attracting much attention, can improve the efficiency of ozonation in water or wastewater treatment. The photocatalytic ozonation will produce more $\mathrm{OH}^{\bullet}$ and $\mathrm{H}_{2} \mathrm{O}_{2}$ species through direct and indirect reaction modes as ozone decomposes [3]. The $\mathrm{OH}^{\bullet}$ is a nonselective oxidant with oxidation potential $\left(E^{0}=2.8 \mathrm{eV}\right)$, compared to ozone $\left(E^{0}=2.08 \mathrm{eV}\right)$, and can react with the refractory pollutant in wastewater [4,5]. In the presence of $\mathrm{TiO}_{2}$, electrons from valence band $\left(\mathrm{e}_{\mathrm{BC}}^{-}\right)$and positive holes 
$\left(\mathrm{h}_{\mathrm{BC}}^{+}\right)$are produced simultaneously under the stimulation of $\mathrm{UV}$ irradiation and the following reactions are proposed to occur [6]:

$$
\begin{aligned}
& \mathrm{TiO}_{2}+h v \rightarrow \mathrm{h}_{\mathrm{BV}}{ }^{+}+\mathrm{e}_{\mathrm{BC}}^{-} \\
& \mathrm{O}_{3}+\mathrm{e}_{\mathrm{BC}}^{-} \rightarrow \mathrm{O}_{3}^{\bullet-} \\
& \mathrm{O}_{3}+\mathrm{O}_{2}^{\bullet-} \rightarrow \mathrm{O}_{3}^{\bullet-}+\mathrm{O}_{2} \\
& \mathrm{O}_{3}^{\bullet-}+\mathrm{H}^{+} \rightarrow \mathrm{HO}_{3}^{\bullet-} \rightarrow \mathrm{O}_{2}+\mathrm{OH}^{\bullet}
\end{aligned}
$$

The Fenton reaction is one popular AOP method in decolorization that combines $\mathrm{Fe}^{2+}$ and $\mathrm{H}_{2} \mathrm{O}_{2}$ with production of $\mathrm{OH}^{\bullet}$, and is also one of the more practical industrial applications demonstrated in recent years [7]. The Fenton reaction is based on the formation of $\mathrm{OH}^{\bullet}$, a nonspecific oxidant with a high $E^{0}$ value that can degrade pollutants efficiently. A typical $\mathrm{OH}^{\bullet}$ formation is shown below:

$$
\mathrm{H}_{2} \mathrm{O}_{2}+\mathrm{Fe}^{2+} \rightarrow \mathrm{Fe}^{3+}+\mathrm{OH}^{-}+\mathrm{OH}^{\bullet}
$$

Decolorization occurs mainly through the reaction of $\mathrm{OH}^{\bullet}$ with dyestuff [8]. The Fenton processes can remove the residual color and $85 \%$ of chemical oxygen demand (COD) from textile wastewater within 20-40 min of reaction time [1].

Electrocoagulation (EC) has been developed in recent years and employs the electrochemical reaction to produce metal ions at the anode, causing the metal ions to immediately undergo further spontaneous reactions to produce corresponding hydroxides and/or polyhydroxides at the cathode [9]. It also generates hydrogen gas as metal anode dissolution. Gas bubbles formed in the cathode, capture suspended solids, and thus removes pollutants by sedimentation or floatation. EC has been studied in textile wastewater treatment and showed almost $100 \%$ decolorization and $70-90 \%$ of COD removal in a previous report [10].

The objective of this study was to evaluate the performance of six AOPs, i.e. $\mathrm{UV} / \mathrm{TiO}_{2}, \mathrm{O}_{3}, \mathrm{O}_{3} / \mathrm{UV}, \mathrm{O}_{3} / \mathrm{UV} / \mathrm{TiO}_{2}$, Fenton and $\mathrm{EC}$, in terms of decolorization and mineralization properties when treating an azo dye, Acid Orange 6 (AO6), and to explore the most efficient experimental conditions as well. The results may serve as a reference for further discussion of economic comparison amongst those AOPs.

\section{Materials and methods}

\subsection{Material}

The chemical structure of AO6 is shown in Fig. 1 and was used without further purification, with a molecular weight and purity of $316 \mathrm{~g} / \mathrm{mol}$ and $65 \%$, respectively. The AO6 stock solution was prepared and the concentration $\left(C_{\mathrm{A} 0}\right)$ was $0.2 \mathrm{~g} / \mathrm{L}$, the

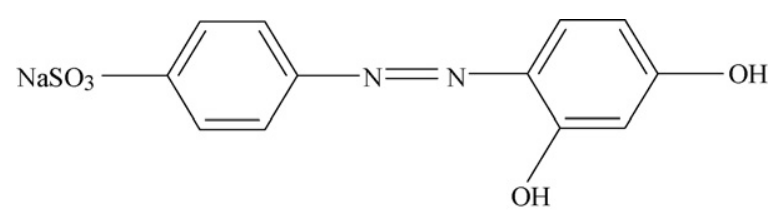

Fig. 1. Molecular structure of Acid Orange 6 (AO6). Molecular formula, $\mathrm{C}_{12} \mathrm{H}_{9} \mathrm{O}_{5} \mathrm{~N}_{2} \mathrm{SNa}$; molecular weight, $316 \mathrm{~g} / \mathrm{mol}$; color index, 14,270. initial values of $\mathrm{pH}, \mathrm{COD}\left(\mathrm{COD}_{0}\right)$ and TOC $\left(\mathrm{TOC}_{0}\right)$ were about $6.8,169 \mathrm{mg} / \mathrm{L}$ and $54 \mathrm{mg} / \mathrm{L}$, respectively. The chemicals for $\mathrm{TiO}_{2}$ (anatase, $99.9+\%$ pure) immobilization, $\mathrm{pH}$ adjustment and TOC analysis in this study were purchased from Aldrich.

\subsection{The ozone reactor}

All ozonation experiments were performed in an airtight reactor with an effective volume of $5.5 \mathrm{~L}$, that was equipped with a water jacket to maintain a constant solution temperature. The operational volume in this study was $4.0 \mathrm{~L}$. Ozone was generated from pure oxygen in an ozone generator (Model SG-01A, Sumitomo, Tokyo, Japan) at a feed rate of $120 \mathrm{~L} / \mathrm{h}$ through a cylindrical gas distributor that was located at the bottom of the reactor, the maximum ozone production is $104 \mathrm{~g} / \mathrm{N} \mathrm{m}^{3}$. The light source used was a low pressure mercury vapor UV lamp (AquaPro, USA) and housed with a quartz glass tube. The UV lamp emitted its maximum radiation at $254 \mathrm{~nm}$, and the irradiation intensity was measured by a digital radiometer (UVX, USA). The $\mathrm{TiO}_{2}$ immobilization was done according to the method reported previously [11] and was coated on the inner surface of a glass tube that was vertically cut in half, and was attached on the inner wall of the reactor. Before starting the semi-batch experiment, ozone containing gas was directed to an ozone monitor (Model 1008-HC, Dasibi, CA, USA), which was previously calibrated with the KI solution and the concentration measured. Excessive ozone gas was destroyed before venting into the air.

\subsection{Fenton}

The Fenton process serves both oxidation and coagulation functions in this study. $\mathrm{H}_{2} \mathrm{O}_{2}$ (Aldrich, $30 \%$ ) and $\mathrm{Fe}^{2+}$ were the major reactants in the oxidation step, and were added to the AO6 solution. The solution was mixed rapidly for $60 \mathrm{~min}$. The $\mathrm{pH}$ for all solution used in this experiment was adjusted by adding $\mathrm{HCl}$ and $\mathrm{NaOH}$, controlling it at desired levels.

\subsection{Electrocoagulation}

The reactor for the EC experiments was designed and the flow diagram is illustrated in Fig. 2. The EC reactor was composed of parallel and horizontal iron plates with an operational volume of 1.0 L. Solution was fed from one side of the case, so that the solution could pass between all spaces between the plates. The regulated direct current (dc) power supplier (Yang Tong, Taiwan) was connected to the top and bottom iron plates that served as cathode and anode. Such a design has been considered an effective EC reactor in treating high concentration of wastewater [9]. The applied voltage used in this study ranges between 0 and $170 \mathrm{~V}$, and the maximum current intensity is $5 \mathrm{~A}$.

\subsection{Experimental procedure}

\subsubsection{Ozonation}

The AO6 stock solution was prepared prior to all ozonation experiments, and the $\mathrm{pH}$ of the AO6 solution was adjusted to the desired value by adding phosphorous buffering solu- 


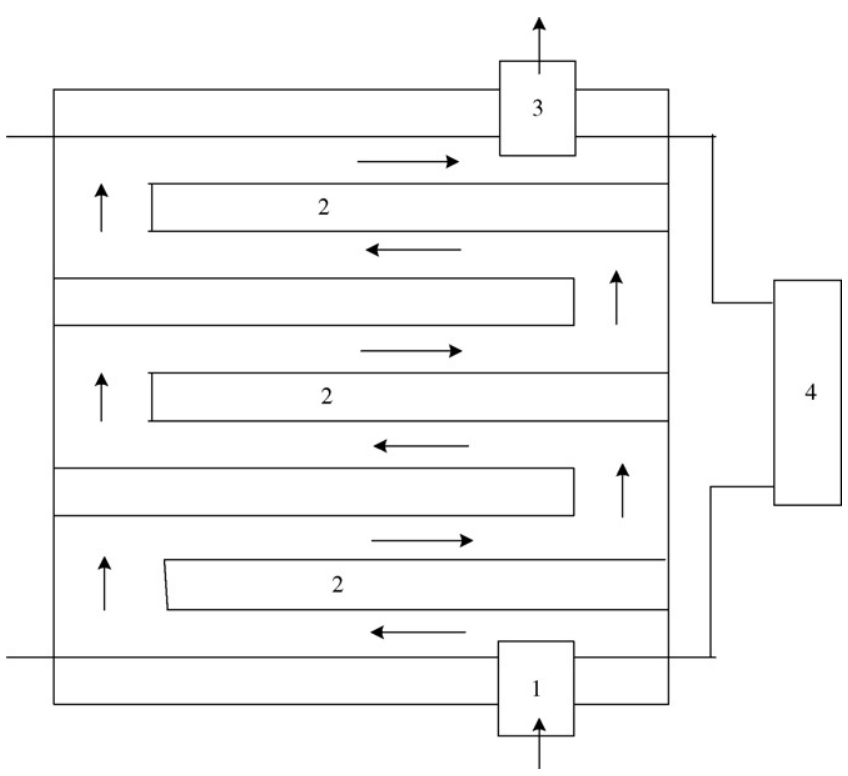

Fig. 2. Flow diagram of EC reactor with short horizontal parallel plate electrodes. Components: (1) solution inlet, (2) electrode, (3) treated solution outlet and (4) dc power supplier.

tion (Aldrich). The experimental conditions were divided into three systems: $\mathrm{O}_{3}$ only, $\mathrm{O}_{3} / \mathrm{UV}$ and $\mathrm{O}_{3} / \mathrm{UV} / \mathrm{TiO}_{2}$ at $25^{\circ} \mathrm{C}$. The inlet ozone gas concentrations $\left(C_{\mathrm{B} 0}\right)$ were set at $36,45,60$ and $80 \mathrm{mg} / \mathrm{L}$ for $\mathrm{O}_{3}$ alone, 0,45 and $60 \mathrm{mg} / \mathrm{L}$ for $\mathrm{O}_{3} / \mathrm{UV}$ experiments and $45 \mathrm{mg} / \mathrm{L}$ for $\mathrm{O}_{3} / \mathrm{UV} / \mathrm{TiO}_{2}$ experiments. For the experiments of $\mathrm{O}_{3} / \mathrm{UV}$ and $\mathrm{O}_{3} / \mathrm{UV} / \mathrm{TiO}_{2}$, mercury lamps emitted $98 \%$ of its total irradiation at $254 \mathrm{~nm}$, UV light intensity used in this experiment was measured as $30 \mathrm{~W} / \mathrm{m}^{2}$. For the $\mathrm{TiO}_{2}$ photocatalytic experiment, $\mathrm{TiO}_{2}$ was pre-coated on the vertically cut glass tubes that were inserted into the reactor before conducting the experiments.

Liquid samples were withdrawn from the reactor at desired time intervals in the course of the experiments to analyze their properties. The residual dissolved ozone in the samples was removed by stripping with nitrogen. According to the test results, the residual dissolved ozone with the initial value of $5 \mathrm{mg} / \mathrm{L}$ could be stripped by nitrogen with more than $98 \%$ (below $0.1 \mathrm{mg} / \mathrm{L}$ ) within $30 \mathrm{~s}$ and complete removal within $60 \mathrm{~s}$ from the solution, as determined by the indigo method [12] with a detection limit of $0.01 \mathrm{mg} / \mathrm{L}$. The sample volume and nitrogen flow rate were $20 \mathrm{~mL}$ and $0.0167 \mathrm{~L} / \mathrm{s}$, respectively. For the ozonation regime with negligible residual dissolved ozone, the sampling time interval did not affect the measurements of absorbance and the TOC of solution. For the ozonation regime with significant residual dissolved ozone, the sampling time interval had to be longer, say $10 \mathrm{~min}$, in order to reduce the lag effect of nitrogen stripping. For the sampling time interval of $10 \mathrm{~min}$, the lag effect of quenching the ozonation reaction on the experimental results is less than $5 \%$ (estimated by noting that $30 \mathrm{~s} / 10 \mathrm{~min}$ is about $5 \%$ ) and may be tolerable.

\subsubsection{Fenton}

The Fenton experiments were carried out in a stirred batch reactor and the temperature was controlled at $25^{\circ} \mathrm{C}$. The stock solution was adjusted to the desired $\mathrm{pH}$ value by adding $\mathrm{HCl}$ and $\mathrm{NaOH} .\left[\mathrm{H}_{2} \mathrm{O}_{2}\right]$ and $\left[\mathrm{Fe}^{2+}\right]$ solutions were prepared from $\mathrm{H}_{2} \mathrm{O}_{2}$ and $\mathrm{FeSO}_{4}$ that were added to stock solution at desired molar ratios. Due to the fast reaction, sampling interval was 1 min per sample taken at the first $10 \mathrm{~min}$. After that, a sampling time interval of $10 \mathrm{~min}$ was set.

\subsubsection{Electrocoagulation}

The stock solution was adjusted to the desired $\mathrm{pH}(4.5,7$ and 10) by adding $\mathrm{HCl}$ and $\mathrm{NaOH}$ and pumped upward through the serpentine channel between the iron plates at a feed rate of $0.9 \mathrm{~L} / \mathrm{min}$, and the effluent was flowed to the storage of stock solution (capacity $=4.0 \mathrm{~L}$ ). The current density and conductivity were set as $86.6 \mathrm{~A} / \mathrm{m}^{2}$ and $200 \mu \mathrm{S} / \mathrm{cm}$, respectively. The samples were collected at 5 and $10 \mathrm{~min}$ intervals from storage.

\subsection{Analytical measurements}

A UV-vis detector (Model Cintra 20, GBC Scientific Equipment, Australia) was used to examine visible wavelength from 400 to $700 \mathrm{~nm}$. The integrated absorbance unit (IAU) was then used to determine the sample color [13]. The TOC concentration was measured by a TOC analyzer (Model 1010, O.I. Corporate, USA) that utilized the UV-persulfate technique to convert the organic carbon for the subsequent analysis by an infrared carbon dioxide analyzer calibrated with the potassium hydrogen phthalate standard.

\section{Results and discussion}

\subsection{Ozonation of AO6 solution}

The results of conventional parameters of ozonated AO6 solution are shown in Table 1 . The $\mathrm{pH}$ decreased during ozonation from 6.8 to about 4.0 whereas the conductivity increased from 211 to $278 \mu \mathrm{S} / \mathrm{cm}$ due to the formation of inorganic acid anions, that could be monitored by the accumulation of nitrate and sulfate in solution. By measuring the characteristic wavelength at $490 \mathrm{~nm}$, AO6 was removed entirely within $40 \mathrm{~min}$ under $C_{\mathrm{B} 0}=45 \mathrm{mg} / \mathrm{L}$. The results of absorbance of the ozonated AO6 solution at the wavelength of $254 \mathrm{~nm}$ were recorded and appeared to decrease as ozonation time increased, suggesting that the aromatic structure and/or double bonds were diminished. Measuring the reduction ratios of $\mathrm{COD}\left(\mathrm{COD} / \mathrm{COD}_{0}\right)$ and TOC $\left(\mathrm{TOC} \mathrm{TOC}_{0}\right)$ under the same reaction time of ozonation, 45 and $35 \%$ of COD and TOC reduction were obtained. It indicated that the oxidation ability of ozone was not adequate to oxidize all organic carbons into carbon dioxide. Therefore, the smaller organic compounds might be produced along with the oxidation of the target compound in the solution, and these were more resistant to ozonation. The $\mathrm{TOC} / \mathrm{TOC}_{0}$ ratios might well represent the status of organic carbon in the solution, but that could not represent the total TOC concentration due to some volatile organic vapors (i.e. formaldehyde and acetaldehyde) generated and emitted with off-gas that were not measured in this study. An existing initial sulfate concentration was noted that was caused by the chemical used to synthesize the AO6 azo 
Table 1

Conventional parameters during the ozonation of the AO6 solution

\begin{tabular}{|c|c|c|c|c|c|c|c|c|}
\hline Time (min) & $\mathrm{pH}$ & Conductivity $(\mu \mathrm{S} / \mathrm{cm})$ & $A / A_{0}(\%)$ & $\mathrm{UV} / \mathrm{UV}_{0}(\%)$ & $\mathrm{COD} / \mathrm{COD}_{0}(\%)$ & $\mathrm{TOC} \mathrm{TOC}_{0}(\%)$ & Sulfate (mg/L) & Nitrate $(\mathrm{mg} / \mathrm{L})$ \\
\hline 0 & 6.81 & 211 & 100.00 & 100.00 & 100.00 & 100.00 & 13.85 & 0 \\
\hline 10 & 6.70 & 223 & 29.09 & 76.93 & 82.45 & 90.83 & 14.62 & 0.39 \\
\hline 20 & 6.27 & 232 & 9.52 & 51.74 & 73.12 & 88.59 & 26.98 & 1.22 \\
\hline 30 & 5.83 & 239 & 5.95 & 35.00 & 66.11 & 82.18 & 34.87 & 1.16 \\
\hline 40 & 4.82 & 245 & 0.81 & 25.04 & 59.98 & 82.03 & 42.51 & 1.90 \\
\hline 50 & 4.26 & 258 & 0 & 16.94 & 55.59 & 80.78 & 47.28 & 2.29 \\
\hline 60 & 3.98 & 278 & 0 & 12.64 & 55.30 & 74.72 & 50.68 & 2.62 \\
\hline
\end{tabular}

Experiment condition: $C_{\mathrm{A} 0}=0.2 \mathrm{~g} / \mathrm{L}, C_{\mathrm{B} 0}=45 \mathrm{mg} / \mathrm{L}$, operational volume $=4 \mathrm{~L}$ and $25^{\circ} \mathrm{C}$.

dye. The net production amount after 60 min of ozonation was $50.7 \mathrm{mg} / \mathrm{L}$. Oxidation and cleavage of the sulfonic acid groups of AO6 resulted in the increment of sulfate. The theoretical sulfate concentration should have been $53.3 \mathrm{mg} / \mathrm{L}$ based on the prescription of $C_{\mathrm{A} 0}=0.2 \mathrm{~g} / \mathrm{L}$ and $65 \%$ of purity, indicating that a small difference exist between the theoretical and the experimental result. It might suggest that some sulfate was not totally released from the ozonated by-products. With regard to nitrate production, an increment in the concentration appeared slowly as ozonation time increased, from none to $2.62 \mathrm{mg} / \mathrm{L}$. Bearing the chemical structure in mind, the nitrate came from the cleavage of azo and derivative amino groups those might contribute to the formation of nitrate as well as nitrite and gaseous nitrogen compounds [14].

\subsection{The effect of ozone concentration, UV irradiation and} $\mathrm{TiO}_{2}$ photocatalyst on the degradation of AO6 and TOC removal

The effects of $C_{\mathrm{B} 0}$ on AO6 reduction was significant and followed a pseudo-first order reaction, as shown in Fig. 3, indicating that the degradation was promoted as the magnitude of $C_{\mathrm{B} 0}$ increased. As for the conditions of $C_{\mathrm{B} 0}=60$ and $80 \mathrm{mg} / \mathrm{L}$, the required time for total AO6 decolorization was shortened, compared with that of $C_{\mathrm{B} 0}=36 \mathrm{mg} / \mathrm{L}$, that was about 25 and $50 \%$ less of the required time needed for the conditions of $C_{\mathrm{B} 0}=36 \mathrm{mg} / \mathrm{L}$.

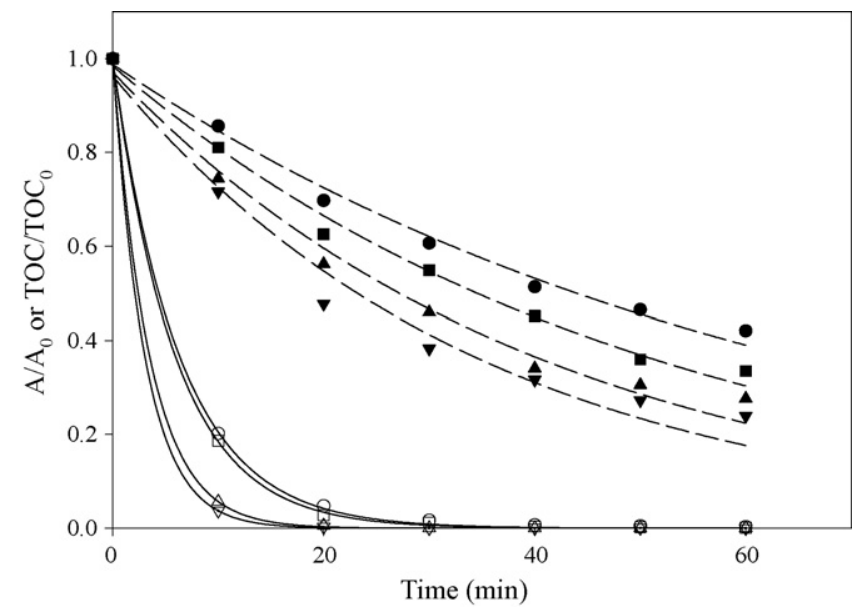

Fig. 3. Effects of different ozone concentrations on the AO6 decolorization and TOC removal. Symbols for AO6 and TOC removal: $(\bigcirc$ and $\bullet) 36 \mathrm{mg} / \mathrm{L}$; ( $\square$ and $\mathbf{\square}) 45 \mathrm{mg} / \mathrm{L} ;(\triangle$ and $\Delta) 60 \mathrm{mg} / \mathrm{L} ;(\nabla$ and $\mathbf{\nabla}) 80 \mathrm{mg} / \mathrm{L}$.
The TOC reduction was not as quick as that of AO6, its reduction rate (in terms of $\mathrm{mg} / \mathrm{L}$ min) increasing as $C_{\mathrm{B} 0}$ increased, as seen in Fig. 3, but the rate of TOC reduction gradually declined, suggesting that intermediate compounds were produced and that they were hard to mineralize.

Fig. 4 shows the effect of $C_{\mathrm{B} 0}$ on the degradation of $\mathrm{AO} 6$ and TOC reduction in the $\mathrm{O}_{3} / \mathrm{UV}$ processes that is similar to $\mathrm{O}_{3}$. Both AO6 and TOC reduction were measured and it was found that almost no reduction efficiencies occurred in the process of UV irradiation alone. It suggested that the chemical structure of AO6 could resist the UV irradiation for $60 \mathrm{~min}$. Thus, the process of UV irradiation alone would not be considered in the following discussion. The AO6 reductions were almost completed within 30 min under $\mathrm{O}_{3} / \mathrm{UV}$ processes, as seen in Fig. 4. For the TOC reduction, it revealed that the reduction efficiency was promoted by the combination of ozonation with UV irradiation, as seen in Fig. 4, and the TOC would be totally removed under the prolonged $\mathrm{O}_{3} / \mathrm{UV}$ process time [15]. That result clearly indicated that the contribution of UV irradiation on catalyzing $\mathrm{O}_{3}$ to produce free radicals was remarkable in removing ozonation by-products.

Fig. 5 shows the comparisons between $\mathrm{UV}, \mathrm{UV} / \mathrm{TiO}_{2}, \mathrm{O}_{3} / \mathrm{UV}$, $\mathrm{O}_{3} / \mathrm{UV} / \mathrm{TiO}_{2}$ and $\mathrm{O}_{3}$ in $\mathrm{AO} 6$ and TOC reduction under the following experimental conditions: $\mathrm{O}_{3}=45 \mathrm{mg} / \mathrm{L}$ and $\mathrm{UV}$ intensity $=30 \mathrm{~W} / \mathrm{m}^{2}$. The processes of $\mathrm{UV}$ and $\mathrm{UV} / \mathrm{TiO}_{2}$ could neither reduce AO6 nor TOC effectively within the experimental time due to the inadequate oxidation ability of both processes. The

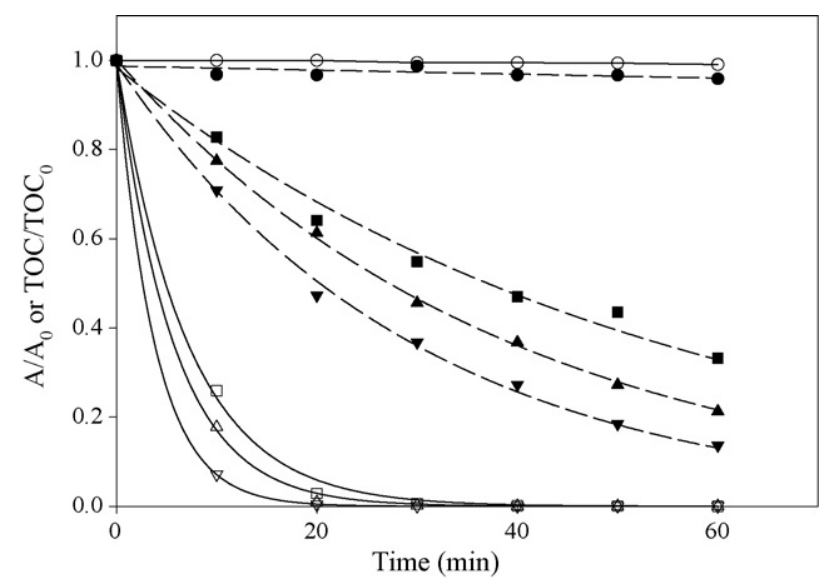

Fig. 4. Effects of ozone concentrations on the AO6 decolorization and TOC removal by $\mathrm{O}_{3} / \mathrm{UV}$ processes. Symbols for AO6 and TOC removal: ( $\bigcirc$ and $O$ ) $0 \mathrm{mg} / \mathrm{L}$; $(\square$ and $\square) 30 \mathrm{mg} / \mathrm{L} ;(\triangle$ and $\Delta$ ) $45 \mathrm{mg} / \mathrm{L} ;(\nabla$ and $\boldsymbol{\nabla}) 60 \mathrm{mg} / \mathrm{L}$. 


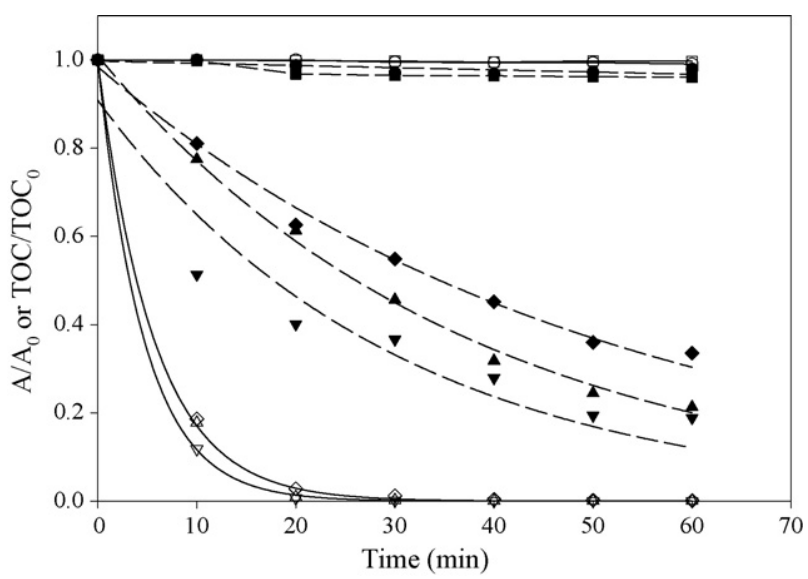

Fig. 5. Effects of photocatalytic ozonation on the AO6 decolorization and TOC removal by $\mathrm{UV}\left(\bigcirc\right.$ and $\mathbf{O}$ ); $\mathrm{UV} / \mathrm{TiO}_{2}$ ( $\square$ and $\left.\boldsymbol{\square}\right) ; \mathrm{O}_{3} / \mathrm{UV}(\triangle$ and $\boldsymbol{\Delta}) ; \mathrm{O}_{3} / \mathrm{UV} / \mathrm{TiO}_{2}$ $(\nabla$ and $\mathbf{\nabla}) ; \mathrm{O}_{3}(\diamond$ and $\diamond)$.

$\mathrm{O}_{3} / \mathrm{UV} / \mathrm{TiO}_{2}$ performed the quickest $\mathrm{AO6}$ reduction rate constant, $0.236 \mathrm{~min}^{-1}$, and the rate constants for $\mathrm{O}_{3}$ and $\mathrm{O}_{3} / \mathrm{UV}$ were 0.137 and $0.218 \mathrm{~min}^{-1}$, respectively. The rate constants are summarized in Table 2. For TOC removal, a similar performance was observed and the TOC reduction rate constant for $\mathrm{O}_{3} / \mathrm{UV} / \mathrm{TiO}_{2}$ was $0.034 \mathrm{~min}^{-1}$, which is 1.7 times of that of the rate constant of $\mathrm{O}_{3}$ and 1.2 times that of $\mathrm{O}_{3} / \mathrm{UV}$ process. As seen in Table 2, it can be noted that the rate constants ratios for $\mathrm{O}_{3} / \mathrm{UV} / \mathrm{TiO}_{2}\left(\left(\right.\right.$ rate constant of $\left.\mathrm{O}_{3} / \mathrm{UV} / \mathrm{TiO}_{2}\right) /($ rate constant of $\left.\mathrm{O}_{3}\right)$ ) and $\mathrm{O}_{3} / \mathrm{UV}$ ((rate constant of $\left.\mathrm{O}_{3} / \mathrm{UV}\right) /($ rate constant of $\left.\mathrm{O}_{3}\right)$ ) of AO6 decolorization are similar to TOC reduction, suggesting that the presence of UV irradiation and/or photocatalyst can significantly promote the oxidation reaction, and the contribution to AO6 decolorization and TOC removal are remarkable. It can thus be concluded clearly from Fig. 5 that the AO6 and TOC reduction efficiencies were in the order of $\mathrm{UV}<\mathrm{UV} / \mathrm{TiO}_{2}<\mathrm{O}_{3}<\mathrm{O}_{3} / \mathrm{UV}<\mathrm{O}_{3} / \mathrm{UV} / \mathrm{TiO}_{2}$.

\subsection{The Fenton process}

\subsubsection{Effect of $p H$}

The Fenton experiments in this study can be divided into two stages, one is to find the optimum $\mathrm{pH}$ for maximum degradation; the other is to apply the optimum $\mathrm{pH}$ and explore the effects of different ratios of $\mathrm{Fe}^{2+}$ to $\left[\mathrm{H}_{2} \mathrm{O}_{2}\right]$ on AO6 degradation. It is known that the Fenton reaction includes the interactions among various inorganic species, i.e. $\mathrm{OH}^{\bullet}, \mathrm{HO}_{2}{ }^{\bullet}, \mathrm{O}^{2-}, \mathrm{H}_{2} \mathrm{O}_{2}, \mathrm{Fe}^{2+}$ and $\mathrm{Fe}^{3+}$, as suggested in a previous study [17], suggesting the $\mathrm{pH}$ value would affect the amount of $\mathrm{OH}^{\bullet}$ generation, and the preferable condition for $\mathrm{OH}^{\bullet}$ generation was under acidic con-

Table 2

The AO6 decolorization and TOC removal rate constants of $\mathrm{O}_{3}, \mathrm{O}_{3} / \mathrm{UV}$ and $\mathrm{O}_{3} / \mathrm{UV} / \mathrm{TiO}_{2}$

\begin{tabular}{llll}
\hline & $\mathrm{O}_{3}$ & $\mathrm{O}_{3} / \mathrm{UV}$ & $\mathrm{O}_{3} / \mathrm{UV} / \mathrm{TiO}_{2}$ \\
\hline AO6 & 0.137 & 0.218 & 0.236 \\
TOC & 0.020 & 0.028 & 0.034 \\
\hline
\end{tabular}

Unit: $\min ^{-1}$.

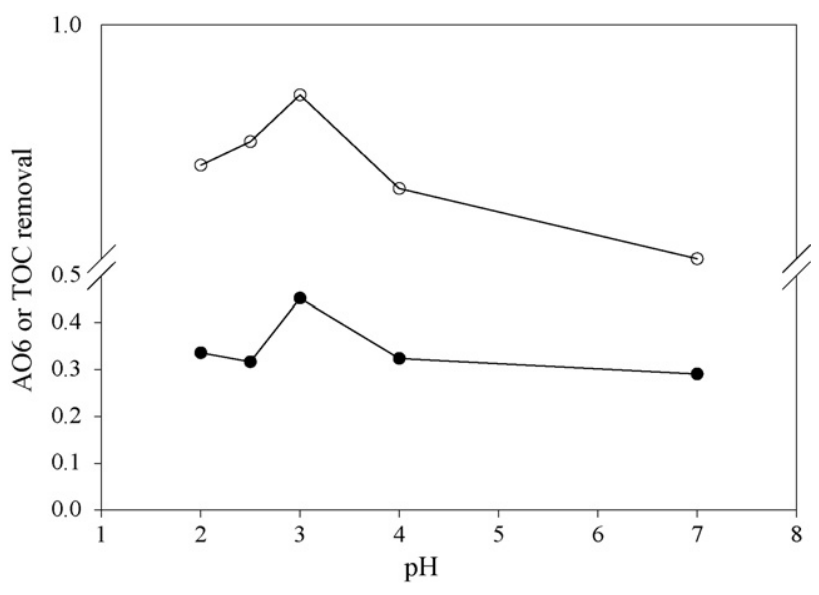

Fig. 6. Effects of $\mathrm{pH}$ on the AO6 decolorization $(\bigcirc)$ and TOC removal $(\bullet)$ during Fenton treatment. Reaction time $=10 \mathrm{~min}, C_{\mathrm{A} 0}=0.2 \mathrm{~g} / \mathrm{L},\left[\mathrm{H}_{2} \mathrm{O}_{2}\right]=29.4 \mathrm{mM}$ $\mathrm{H}_{2} \mathrm{O}_{2},\left[\mathrm{Fe}^{2+}\right]=4.5 \mathrm{mM} \mathrm{Fe}(\mathrm{II})$.

ditions. Thus, an optimum $\mathrm{pH}$ for maximum degradation of the aqueous AO6 dye solutions was studied and reactions were carried out at different $\mathrm{pH}$ values in the range of 2-7 by adding $\mathrm{H}_{2} \mathrm{SO}_{4}$ or $\mathrm{NaOH}$ to adjust the $\mathrm{pH}$ value. Fig. 6 represents the ratios of $\mathrm{AO6}$ decolorization (denoted as $\left.1-\left(A / A_{0}\right)\right)$ and TOC removal (denoted as $\left.1-\left(\mathrm{TOC}_{\mathrm{TOC}}\right)\right)$ at different $\mathrm{pH}$ values of 2, 2.5, 3, 4 and 7, i.e. under acidic and neutral conditions. The results show that the ratios of AO6 decolorization and TOC removal decreased as $\mathrm{pH}$ value increased, and the optimum $\mathrm{pH}$ for AO6 was found to be $\mathrm{pH} \mathrm{3,} \mathrm{a} \mathrm{result} \mathrm{found} \mathrm{to} \mathrm{be} \mathrm{similar} \mathrm{to}$ others found in literature [8,17]. Increasing the $\mathrm{pH}$ from 3 to 7 , the AO6 decolorization ratio decreases from 0.97 to 0.9 and TOC removal ratio decreases from 0.45 to 0.29 sharply. As $\mathrm{pH}$ decreases from 3 to 2, the AO6 decolorization ratio decreases slightly, from 0.97 to 0.94 , and TOC removal ratio decreases from 0.45 to 0.34 . Furthermore, $\mathrm{Fe}^{3+}$ complex precipitation was formed that can explain the low activity as $\mathrm{pH}$ value increases $[18,19]$. In these $\mathrm{pH}$ tests, the decrease in AO6 decolorization and TOC removal is due to the reaction of $\mathrm{Fe}^{2+}$ and $\mathrm{OH}^{\bullet}$ that forms $\mathrm{Fe}^{3+}$ [16]. Because of the scavenging effect of $\mathrm{H}^{+}$at low $\mathrm{pH}$ conditions, the removal rates were limited so that $\mathrm{H}^{+}$would react with $\mathrm{OH}^{\bullet}$ and formed $\mathrm{H}_{2} \mathrm{O}$ [20].

\subsubsection{The effect of $\mathrm{H}_{2} \mathrm{O}_{2}$ and ferrous ion dosages}

Effect of the different ratios of $\left[\mathrm{H}_{2} \mathrm{O}_{2}\right]$ to $\left[\mathrm{Fe}^{2+}\right]$ on $\mathrm{AO} 6$ degradation and TOC removal were evaluated and performed under $\mathrm{pH} 3$ conditions, as shown in Fig. 7a and b. The results obtained for AO6 and TOC reduction as a function of the initial molar concentration ratio of $\mathrm{H}_{2} \mathrm{O}_{2} / \mathrm{Fe}^{2+}(\mathrm{mM} / \mathrm{mM}$, denoted as $\mathrm{HF}$ ) are presented. Under $\left[\mathrm{Fe}^{2+}\right]=8.93 \mathrm{mM}$, the results show that the maximum AO6 and TOC reduction could teach 0.97 and 0.45 by applying six hydrogen peroxide concentrations, of which HFs $=0.82,1.65,3.29,4.95,6.58,8.25$, to the dye solution. The optimum $\mathrm{HF}$ was 6.58 that represented the $\left[\mathrm{H}_{2} \mathrm{O}_{2}\right]$ to $\left[\mathrm{Fe}^{2+}\right]$ molar ratio as $58.82 \mathrm{mM}\left(\mathrm{H}_{2} \mathrm{O}_{2}\right)$ to $8.93 \mathrm{mM}\left(\mathrm{Fe}^{2+}\right)$, suggesting that $\mathrm{HF}=6.58$ might serve as the optimum molar ratio in treating AO6 solution. Some studies related to the optimum molar ratio for the Fenton system had been proposed in treating chlorinated 


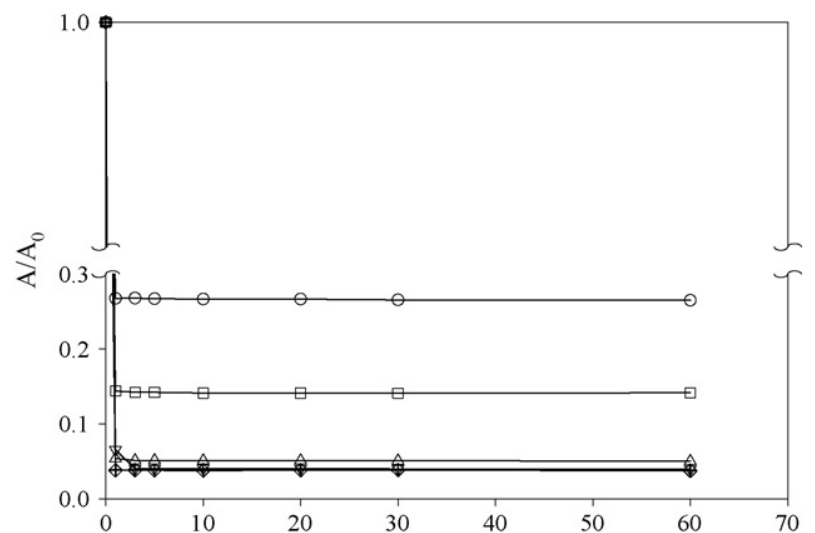

(a)

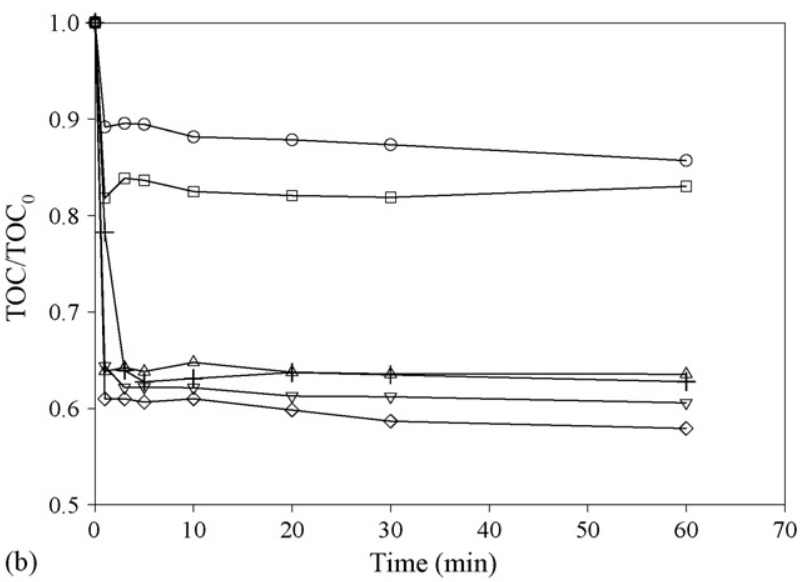

Fig. 7. Effects of $\mathrm{H}_{2} \mathrm{O}_{2}$ to $\mathrm{Fe}^{2+}$ ratios (HF) on: (a) AO6 decolorization and (b) TOC removal. Symbols: $(\bigcirc) \mathrm{HF}=0.82 ;(\square) \mathrm{HF}=1.65 ;(\triangle) \mathrm{HF}=3.29 ;(\nabla)$ $\mathrm{HF}=4.95 ;(\diamond) \mathrm{HF}=6.58 ;(+) \mathrm{HF}=8.25$.

aliphatic organic pollutants [21] and cork-processing wastewater [22] which were 5-11 and 10, respectively. As expected, the applied $\mathrm{H}_{2} \mathrm{O}_{2}$ dosage was the controlling factor of AO6 decolorization and TOC removal, which were consumed in the early stage of the reaction. The $\mathrm{H}_{2} \mathrm{O}_{2}$ dosage was increased from 14.7 to $58.82 \mathrm{mM}$, the AO6 decolorization ratio increased from 0.73 to 0.96 at $5 \mathrm{~min}$ of reaction time, indicating that the increase of AO6 decolorization ratio was due to the increase
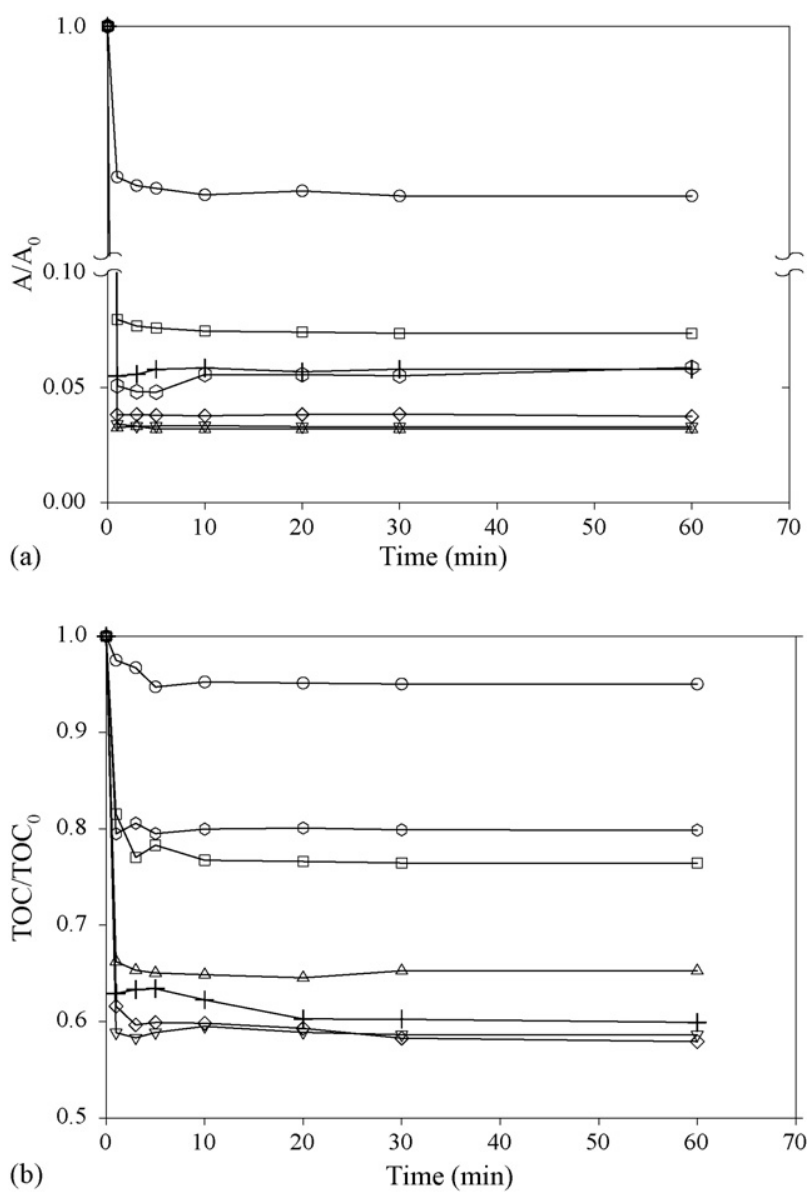

Fig. 8. Effects of initial molar concentration ratio of $\mathrm{H}_{2} \mathrm{O}_{2}: \mathrm{Fe}^{2+}$ (mM:mM) under $\mathrm{HF}=6.58$ on the (a) AO6 decolorization and (b) TOC removal. Symbols: $(\bigcirc) \mathrm{H}_{2} \mathrm{O}_{2}: \mathrm{Fe}^{2+}=2.94: 0.45 ;(\square) \mathrm{H}_{2} \mathrm{O}_{2}: \mathrm{Fe}^{2+}=14.7: 2.23 ;(\triangle) \mathrm{H}_{2} \mathrm{O}_{2}: \mathrm{Fe}^{2+}=$ 29.41:4.46; $(\nabla) \mathrm{H}_{2} \mathrm{O}_{2}: \mathrm{Fe}^{2+}=44.11: 6.70 ;(\diamond) \mathrm{H}_{2} \mathrm{O}_{2}: \mathrm{Fe}^{2+}=58.82: 8.93 ; \quad(+)$ $\mathrm{H}_{2} \mathrm{O}_{2}: \mathrm{Fe}^{2+}=73.53: 11.16 ;(\square) \mathrm{H}_{2} \mathrm{O}_{2}: \mathrm{Fe}^{2+}=88.24: 13.39$.

in $\mathrm{OH}^{\bullet}$ concentration through the addition of $\mathrm{H}_{2} \mathrm{O}_{2}$, as seen in Fig. 8. Further addition of $\mathrm{H}_{2} \mathrm{O}_{2}>73.53 \mathrm{mM}$ would inhibit the AO6 decolorization and TOC removal, that ratios are listed in Table 3. The inhibition under $\mathrm{H}_{2} \mathrm{O}_{2}$ higher dosage in the decolorization may due to the $\mathrm{OH}^{\bullet}$ scavenging effect of $\mathrm{H}_{2} \mathrm{O}_{2}$ [23] and recombination of hydroxyl radicals [24].

Table 3

The AO6 and TOC reduction ratio under various HFs at $60 \mathrm{~min}$

\begin{tabular}{lllll}
\hline$\left[\mathrm{H}_{2} \mathrm{O}_{2}\right](\mathrm{mM})$ & {$\left[\mathrm{Fe}^{2+}\right](\mathrm{mM})$} & $\mathrm{HF}(\mathrm{mM} / \mathrm{mM})$ & AO6 reduction $\left(A / A_{0}\right)$ & TOC reduction $(\mathrm{TOC} / \mathrm{TOC})_{0}$ \\
\hline 14.70 & 17.85 & 0.82 & 0.265 & 0.857 \\
14.70 & 8.93 & 1.65 & 0.140 & 0.830 \\
29.41 & 8.93 & 3.29 & 0.050 & 0.636 \\
44.12 & 8.93 & 4.95 & 0.040 & 0.606 \\
58.82 & 8.93 & 6.58 & 0.037 & 0.579 \\
73.53 & 8.93 & 8.25 & 0.037 & 0.628 \\
2.94 & 0.45 & 6.58 & 0.852 & 0.950 \\
14.7 & 2.23 & 6.58 & 0.074 & 0.764 \\
29.41 & 4.46 & 6.58 & 0.032 & 0.652 \\
44.11 & 6.70 & 6.58 & 0.033 & 0.586 \\
58.82 & 8.93 & 6.58 & 0.037 & 0.579 \\
73.53 & 11.16 & 6.58 & 0.058 & 0.598 \\
88.24 & 13.39 & 6.58 & 0.059 & 0.598 \\
\hline
\end{tabular}


Under the same $\mathrm{HF}$, the increase of $\left[\mathrm{H}_{2} \mathrm{O}_{2}\right]$ from 2.94 to $29.41 \mathrm{mM}$ decreased the $C / C_{0}$ value from 0.852 to 0.032 and 0.95 to 0.652 for TOC/TOC 0 . Further addition of $\left[\mathrm{H}_{2} \mathrm{O}_{2}\right]$ from 29.41 to $88.24 \mathrm{mM}$ and $\left[\mathrm{Fe}^{2+}\right]$ from 4.46 to $13.39 \mathrm{mM}$, did not improve the AO6 decolorization ratios; the TOC removal ratios were slightly enhanced from 0.35 to 0.42 as $\left[\mathrm{H}_{2} \mathrm{O}_{2}\right] /\left[\mathrm{Fe}^{2+}\right]=58.82 / 8.93(\mathrm{mM} / \mathrm{mM})$, and then, the removal ratio did not improve as both $\left[\mathrm{H}_{2} \mathrm{O}_{2}\right]$ and $\left[\mathrm{Fe}^{2+}\right]$ increased with the same HF. Thus, the optimum initial molar concentration of $\left[\mathrm{H}_{2} \mathrm{O}_{2}\right]$ and $\left[\mathrm{Fe}^{2+}\right]$ in treating AO6 solution $\left(\mathrm{C}_{\mathrm{A} 0}=0.2 \mathrm{~g} / \mathrm{L}\right)$ can be concluded as $\left[\mathrm{H}_{2} \mathrm{O}_{2}\right]=58.82 \mathrm{mM}$ and $\left[\mathrm{Fe}^{2+}\right]=8.93 \mathrm{mM}$.

\subsection{Electrocoagulation process}

The experiments using the EC process in this study were intended to explore the effects of applied voltages and $\mathrm{pH}$ on AO6 decolorization and TOC removal. The EC process includes three reactions: electrolytic reactions, coagulant formation, and removal of the coagulation of the pollutant with coagulant by floatation or sedimentation [25].

The effect of $\mathrm{pH}$ was investigated and carried out at $\mathrm{pH} 4.5,7$ and 10 with $C_{\mathrm{A} 0}=0.2 \mathrm{~g} / \mathrm{L}$. The current density and conductivity were maintained at $86.6 \mathrm{~A} / \mathrm{m}^{2}$ and $200 \mu \mathrm{S} / \mathrm{cm}$, respectively. The $\mathrm{pH}$ of the effluent was affected by the applied voltages, and a $\mathrm{pH}$ increase occurred when the solution $\mathrm{pH}$ was low, but the $\mathrm{pH}$ would decrease if the solution $\mathrm{pH}$ was above 9 with 5 min of reaction time, indicating that the $\mathrm{EC}$ and flotation process can act as a $\mathrm{pH}$ neutralizer during the oxidation reaction (Fig. 9). From Fig. 9, the $\mathrm{pH}$ of effluents reached a steady state in the range of 9-10, at applied voltage larger than $80 \mathrm{~V}$, suggesting that applied voltage might serve as criteria in neutralizing the AO6 solution.

Fig. 10 demonstrates the AO6 decolorization and TOC removal as a function of the solution $\mathrm{pH}$, suggesting that better AO6 decolorization and TOC removal can be achieved under acidic influent conditions within $5 \mathrm{~min}$ of reaction time. The decolorization rate of AO6 decreased from 0.97 to 0.42 and TOC decreased from 0.23 to 0.13 as initial $\mathrm{pH}$ increased from 4.5 to 10 , but the $\mathrm{pH}$ of effluents were not so significant in

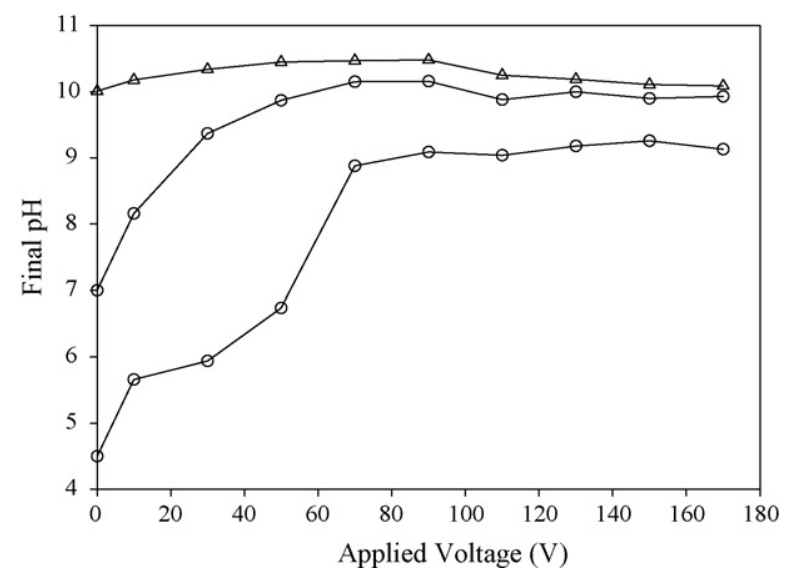

Fig. 9. The effect of applied voltage on the effluent $\mathrm{pH}$. Symbols: $(\bigcirc) \mathrm{pH} 4.5$; $(\square) \mathrm{pH} 7 ;(\triangle) \mathrm{pH} 10$.

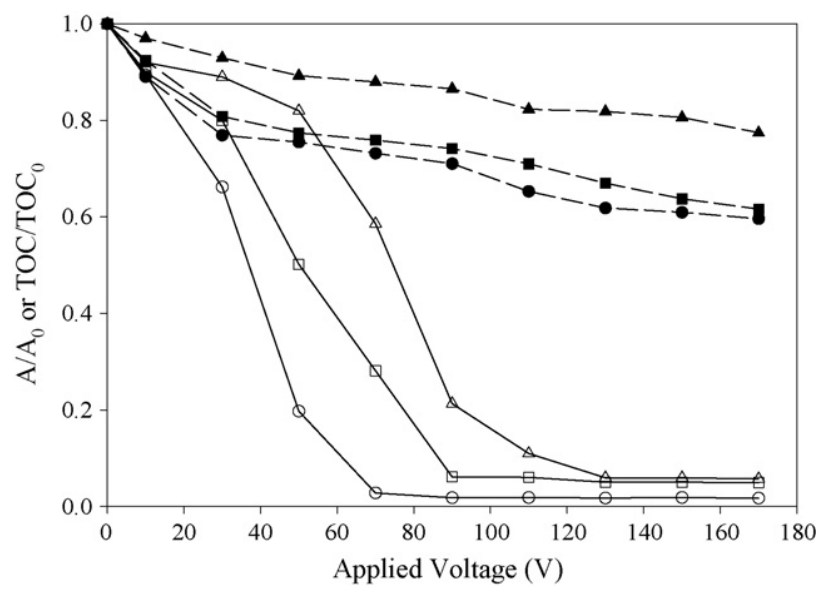

Fig. 10. The effect of initial $\mathrm{pH}$ on the (a) AO6 decolorization and (b) TOC removal. Symbols for AO6 and TOC removal: $(\bigcirc$ and $\bigcirc) \mathrm{pH}=4.5$; ( $\square$ and $\mathbf{\square})$ $\mathrm{pH}=7 ;(\triangle$ and $\boldsymbol{\Delta}) \mathrm{pH}=10$.

the range of 9-10. This indicates that dye solution under low initial $\mathrm{pH}$ conditions might be favorable for target compound and TOC removal. Furthermore, the applied voltage also acts as an important factor in the EC process, in that the AO6 decol-
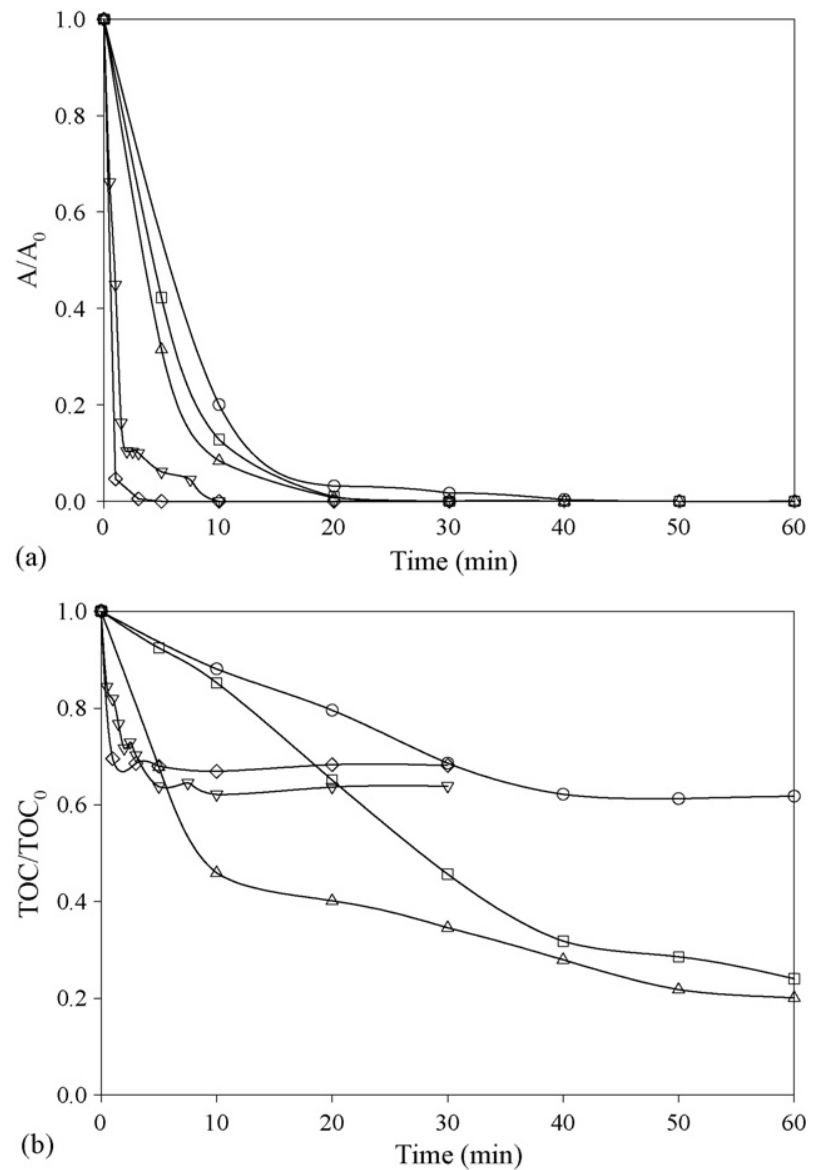

Fig. 11. Effect of various methods on: (a) AO6 decolorization and (b) TOC removal by $\mathrm{O}_{3}(\bigcirc), \mathrm{O}_{3} / \mathrm{UV}(\square), \mathrm{O}_{3} / \mathrm{UV} / \mathrm{TiO}_{2}(\triangle)$, EC $(\nabla)$ and Fenton $(\diamond)$. Experimental condition: $\mathrm{O}_{3}=45 \mathrm{mg} / \mathrm{L}$; $\mathrm{UV}$ intensity $=30 \mathrm{~W} / \mathrm{m}^{2} ; \mathrm{TiO}_{2}$ coated plates; $\mathrm{pH} 7$ for $\mathrm{O}_{3}, \mathrm{O}_{3} / \mathrm{UV}$ and $\mathrm{O}_{3} / \mathrm{UV} / \mathrm{TiO}_{2}, \mathrm{pH} 3$ for Fenton process, $\mathrm{pH} 3$ for EC process; $\left[\mathrm{H}_{2} \mathrm{O}_{2}\right]=58.82 \mathrm{mM}$ and $\left[\mathrm{Fe}^{2+}\right]=8.93 \mathrm{mM}$; applied voltage $=80 \mathrm{~V}$; $C_{\mathrm{A} 0}=0.2 \mathrm{~g} / \mathrm{L}$; temperature $=25^{\circ} \mathrm{C}$. 
orization and TOC removal are enhanced as applied voltage is increased.

\subsection{The AOPs performance on the removing of AO6 and TOC}

The AO6 decolorization and TOC removal efficiency results of selected AOP methods are illustrated in Fig. 11a and b. It was noted that the EC and Fenton processes were more effective in AO6 decolorization, in that both could remove AO6 within $10 \mathrm{~min}$, compared to photocatalytic ozonation processes. The AO6 decolorization rate was in the order of $\mathrm{O}_{3}<\mathrm{O}_{3} / \mathrm{UV}=\mathrm{O}_{3} / \mathrm{UV} / \mathrm{TiO}_{2}<\mathrm{EC}<$ Fenton, as seen in Fig. 11a. The rank of TOC removal rate for $30 \mathrm{~min}$ of reaction time was in the order of $\mathrm{O}_{3}=$ Fenton $<\mathrm{EC}<\mathrm{O}_{3} / \mathrm{UV}<\mathrm{O}_{3} / \mathrm{UV} / \mathrm{TiO}_{2}$, indicating that photocatalytic ozonation processes performed better in mineralization, as in Fig. 11b. As seen in Fig. 11b, the TOC removal for EC and Fenton processes was not significant after $10 \mathrm{~min}$ of reaction time. A longer reaction time, say $30 \mathrm{~min}$, might not improve mineralization efficiency. It suggested that the EC and Fenton processes were suitable for the decolorization of industrial wastewater rather than for mineralization.

\section{Conclusions}

The comparison of different AOPs is, on the one hand, of interest to determine the best removal performance and the most efficient experimental conditions for the destruction of target compound in dye solution, and, on the other hand, to provide useful information for the baseline of the combination of different AOPs in treating industrial wastewater. The following conclusions can be drawn from the experimental work:

- Photocatalytic ozonation exhibits remarkable TOC removal efficiency, in that both $\mathrm{O}_{3} / \mathrm{UV}$ and $\mathrm{O}_{3} / \mathrm{UV} / \mathrm{TiO}_{2}$ processes can achieve $65 \%$ of removal efficiency at $\mathrm{pH} 7$ and $C_{\mathrm{B} 0}=45 \mathrm{mg} / \mathrm{L}$. The removal efficiencies are enhanced with an increase in $\mathrm{O}_{3}$ dose.

- The optimum $\mathrm{pH}$ and the ratio of $\left[\mathrm{H}_{2} \mathrm{O}_{2}\right] /\left[\mathrm{Fe}^{2+}\right]$ found for the Fenton process, were $\mathrm{pH} 4$ and $\left[\mathrm{H}_{2} \mathrm{O}_{2}\right] /\left[\mathrm{Fe}^{2+}\right]=6.58$. The optimum $\left[\mathrm{H}_{2} \mathrm{O}_{2}\right]$ and $\left[\mathrm{Fe}^{2+}\right]$ under the same $\mathrm{HF}$ value, were 58.82 and $8.93 \mathrm{mM}$, respectively.

- The optimum applied voltage for the EC experiment is $80 \mathrm{~V}$. The initial $\mathrm{pH}$ will affect the rates of AO6 decolorization and TOC removal, in that acidic conditions may be favorable for higher removal rate.

- Among the investigated AOPs in this study, the quickest AO6 decolorization rate was obtained by Fenton process. The ranking was in the order of $\mathrm{UV}=\mathrm{UV} / \mathrm{TiO}_{2}<\mathrm{O}_{3}<\mathrm{O}_{3} / \mathrm{UV}=$ $\mathrm{O}_{3} / \mathrm{UV} / \mathrm{TiO}_{2}<\mathrm{EC}<$ Fenton. Further, the performance of selected AOPs on TOC removal was in the order of $\mathrm{UV}<\mathrm{UV} / \mathrm{TiO}_{2}<\mathrm{O}_{3}=$ Fenton $<\mathrm{EC}<\mathrm{O}_{3} / \mathrm{UV}<\mathrm{O}_{3} / \mathrm{UV} / \mathrm{TiO}_{2}$. Since the $\mathrm{O}_{3}$ treatment is not merely based on the $\mathrm{OH}^{\bullet}$ concentration due to a smaller $E^{0}$ value $(=2.08 \mathrm{~V})$, TOC removal rate for ozonation only is lower than other AOPs after $30 \mathrm{~min}$ of reaction time.

\section{Acknowledgement}

The support of this project by the National Science Council (Project No. NSC 91-2211-E-002-024) of Executive Yuan, ROC, is gratefully acknowledged.

\section{References}

[1] S.F. Kang, H.M. Chang, Coagulation of textile secondary effluents with Fenton's reagent, Wat. Sci. Technol. 36 (1997) 215-222.

[2] P.C. Chiang, Y.W. Ko, C.H. Liang, E.E. Chang, Modeling an ozone bubble column for predicting its disinfection efficiency and control of DBP formation, Chemosphere 39 (1999) 55-70.

[3] G.R. Peyton, W.H. Glaze, Destruction of pollutants in water with ozone in combination with ultraviolet radiation. 3. Photolysis of aqueous ozone, Env. Sci. Technol. 22 (1988) 761-767.

[4] L. Li, W. Zhu, P. Zhang, Z. Chen, W. Han, Photocatalytic oxidation and ozonation of catechol over carbon-black-modified nano- $\mathrm{TiO}_{2}$ thin films supported on Al sheet, Wat. Res. 37 (2003) 3646-3651.

[5] C. Tang, V. Chen, The photocatalytic degradation of Reactive Black 5 using $\mathrm{TiO}_{2} / \mathrm{UV}$ in an annular photoreactor, Wat. Res. 38 (2004) 27752781.

[6] P. Pichat, L. Cermenati, A. Albini, D. Mas, H. Delprat, C. Guillard, Degradation processes of organic compounds over $\mathrm{UV}$-irradiated $\mathrm{TiO}_{2}{ }^{\bullet}$ effect of ozone, Res. Chem. Intermed. 26 (2000) 161-170.

[7] S. Meriç, N. Kaptan, T. Ölmez, Color and COD removal from wastewater containing Reactive Black 5 using Fenton's oxidation process, Chemosphere 54 (2004) 435-441.

[8] S.-F. Kang, C.-H. Liaob, M.-C. Chen, Pre-oxidation and coagulation of textile wastewater by the Fenton process, Chemosphere 46 (2002) 923928.

[9] M.Y.A. Mollah, P. Morkovsky, J.A.G. Gomes, M. Kesmez, J. Parga, D.L. Cockec, Fundamentals, present and future perspectives of electrocoagulation, J. Hazard. Mater. B114 (2004) 199-210.

[10] G. Ciardelli, N. Ranieri, The treatment and reuse of wastewater in the textile industry by means of ozonation and electroflocculation, Wat. Res. 35 (2001) 567-572.

[11] K. Tanaka, K. Abe, T. Hisanaga, Photocatalytic water treatment on immobilized $\mathrm{TiO}_{2}$ with ozonation, J. Photchem. Photobiol. A 101 (1996) 8587.

[12] APHA, Standard Methods for The Examination of Water and Wastewater, 19th ed., American Public Health Association, Washington, DC, 1995.

[13] J. Wu, T. Wang, Ozonation of aqueous azo dye in a semi-batch reactor, Wat. Res. 35 (2001) 1093-1099.

[14] L. Oliviero, J. Barbier, D. Duprez, Wet air oxidation of nitrogen-containing organic compounds and ammonia in aqueous media, Appl. Catal. B 40 (2003) 163-184.

[15] Y.H. Chen, C.Y. Chang, S.F. Huang, C.Y. Chiu, D. Ji, N.C. Shang, Y.H. Yu, P.C. Chiang, Y. Ku, J.N. Chen, Decomposition of 2-naphthalenesulfonate in aqueous solution by ozonation with UV radiation, Wat. Res. 36 (2002) 4144-4154.

[16] M. Neamtu, A. Yediler, I. Siminiceanu, A. Kettrup, Oxidation of commercial reactive azo dye aqueous solutions by the photo-Fenton and Fenton-like processes, J. Photchem. Photobiol. A 161 (2003) 87-93.

[17] X.-R. Xu, H.-B. Li, W.-H. Wang, J.-D. Gu, Degradation of dyes in aqueous solutions by the Fenton process, Chemosphere 57 (2004) 595-600.

[18] -M.J. Lee, M.-S. Kim, B. Hwang, W. Bae, B.-W. Kim, Photodegradation of Acid Red 114 dissolved using a photo-Fenton process with $\mathrm{TiO}_{2}$, Dyes Pigments 56 (2003) 59-67.

[19] M. Pérez, F. Torrades, X. Domènech, J. Peral, Fenton and photo-Fenton oxidation of textile effluents, Wat. Res. 36 (2002) 2703-2710.

[20] J.W.T. Spinks, R.J. Woods, An Introduction to Radiation Chemistry, third ed., John Wiley \& Sons, New York, NY, 1990.

[21] W.Z. Tang, C.P. Huang, Stoichiometry of Fenton's reagent in the oxidation of chlorinated aliphatic organic pollutants, Env. Technol. 18 (1997) 1323. 
[22] J. Heredia, J.R. Domínguez, R. López, Advanced oxidation of corkprocessing wastewater using Fenton's reagent: kinetics and stoichiometry, J. Chem. Technol. Biotechnol. 79 (2004) 407-412.

[23] M. Muruganandham, M. Swaminathan, Decolourisation of Reactive Orange 4 by Fenton and photo-Fenton oxidation technology, Dyes Pigments 63 (2004) 315-321.
[24] C.H. Welling, Fenton's reagent revisited, Acc. Chem. Res. 8 (1975) 125-131.

[25] O.T. Can, M. Bayramoglu, M. Kobya, Decolorization of Reactive dye solutions by electrocoagulation using aluminum electrodes, Ind. Eng. Chem. Res. 42 (2003) 3391-3396. 